\title{
Healthcare workers' industrial action in Nigeria: a cross-sectional survey of Nigerian physicians
}

\author{
Obinna Ositadimma Oleribe ${ }^{1^{*}}$ (D), Deborah Udofia ${ }^{1}$, Olabisi Oladipo², Temitope Arike Ishola ${ }^{1}$ \\ and Simon D. Taylor-Robinson ${ }^{3}$
}

\begin{abstract}
Background: The Nigerian health system has been plagued with numerous healthcare worker strikes (industrial action) at all levels. The purpose of this study is to document physicians' views on healthcare worker-initiated strike action in Nigeria and represent a follow-on to a previous study where poor leadership and management were cited as the most common cause of strike action by healthcare workers.

Methods: A cross-sectional, descriptive study was executed between April and June 2017. We used a selfadministered pre-tested structured questionnaire with open-ended questions to allow for better expression of participants' views. Participants were drawn mainly from the recently concluded West African College of Physicians (WACP)/Royal College of Physicians (RCP) Millennium Development Goal 6 Partnership for African Clinical Training (M-PACT) course. They represented the six geopolitical zones of Nigeria. Data were analysed using SPSS $\vee 23$. Simple frequencies were performed, and relevant tables/charts were developed.

Results: A total of 58 physicians (out of 131 participants reached) responded to the study, giving a response rate of $44.3 \% .62 .1 \%$ were males, $67.9 \%$ were between the ages of 30 and 39 years, and over $60 \%$ of respondents graduated prior to 2010. Poor staff welfare was cited by $16.7 \%$ as the commonest cause of strikes in the healthcare system. Other causes cited were salary issues (13.9\%), leadership and management (13.9\%), poor hospital infrastructure (11.1\%), poor guidelines and services (11.1\% each) and inter-professional disputes (5.6\%). The negative consequences of strikes, the groups who benefit from them and solutions to the strikes were enumerated, including training physicians in leadership skills by $98.2 \%$ of respondents.

Conclusion: Poor staff welfare, salary and leadership/management and governmental inability to implement agreements were the common causes of healthcare worker strikes in this study. These strikes resulted in disruption to service delivery and training programmes, increased morbidity and mortality of patients and loss of confidence in the hospitals and the healthcare professions. The participants recommended that the Federal Government respects agreements made with the management of healthcare institutions, implements the National Health Act and ensures that only leaders and managers who are formally trained are appointed to healthcare management positions.
\end{abstract}

Keywords: Healthcare workers, Physicians, Industrial actions, Strike, Nigeria

\footnotetext{
* Correspondence: obinna.oleribe@expertmanagers.org

${ }^{1}$ Excellence \& Friends Management Care Centre (EFMC), P. O. Box 200, PSIN

Dutse, Abuja, Nigeria

Full list of author information is available at the end of the article
}

(c) The Author(s). 2018 Open Access This article is distributed under the terms of the Creative Commons Attribution 4.0 International License (http://creativecommons.org/licenses/by/4.0/), which permits unrestricted use, distribution, and reproduction in any medium, provided you give appropriate credit to the original author(s) and the source, provide a link to the Creative Commons license, and indicate if changes were made. The Creative Commons Public Domain Dedication waiver (http://creativecommons.org/publicdomain/zero/1.0/) applies to the data made available in this article, unless otherwise stated. 


\section{Background}

The healthcare provision in Nigeria has suffered greatly from numerous healthcare worker strikes (industrial action) over the years. These have resulted in multiple avoidable mortalities and morbidities in Nigeria, further destroying the already poor health outcomes in the country. As documented in an earlier study, strikes have remained common occurrences in Nigeria as there are local, state, regional and sometimes national industrial action on a regular basis [1]. A recent review shows that between April 2016 and April 2017, there were at least 17 different strike actions in Nigeria involving public workers [2-6].

\begin{tabular}{|c|c|c|}
\hline $\mathrm{S} / \mathrm{No}$ & Description & Date \\
\hline 1 & All Imo State Doctors & February 2016 \\
\hline 2 & Imo State University & March 2016 \\
\hline 3 & Kogi State University & April 2016 \\
\hline 4 & University of Lagos & April 2016 \\
\hline 5 & $\begin{array}{l}\text { Adekunle Ajasin University, } \\
\text { Akungba-Akoko (AAUA) }\end{array}$ & April 2016 \\
\hline 6 & University of Ibadan & April 2016 \\
\hline 7 & Obafemi Awolowo University & June 2016 \\
\hline 8 & Federal Medical Centre, Ondo & Mid 2016 \\
\hline 9 & Ladoke Akintola University & June 2016 \\
\hline 10 & $\begin{array}{l}\text { Federal University of Agriculture } \\
\text { Abeokuta }\end{array}$ & August 2016 \\
\hline 11 & Ebonyi State University & October 2016 \\
\hline 12 & Ambrose Ali University & October 2016 \\
\hline 13 & $\begin{array}{l}\text { Nigeria Union of Petroleum and } \\
\text { Natural Gas and PENGASSAN }\end{array}$ & January 2017 \\
\hline 14 & $\begin{array}{l}\text { National Orthopaedic Hospital, } \\
\text { lgbobi, Lagos (NOHIL) }\end{array}$ & March 2017 \\
\hline 15 & $\begin{array}{l}\text { Nigerian Union of Allied Health } \\
\text { Professionals (dental therapists, } \\
\text { medical physicists, health } \\
\text { information officers, clinical } \\
\text { psychologists and medical } \\
\text { social workers) }\end{array}$ & March 2017 \\
\hline 16 & Federal Medical Centre, Yenogoa & May 2017 \\
\hline 17 & $\begin{array}{l}\text { Benue State University Teaching } \\
\text { Hospital Joint Health Sector Union } \\
\text { (JOHESU) chapter }\end{array}$ & May 2017 \\
\hline
\end{tabular}

Of the 17 documented and reported strike actions, six were primarily within the healthcare establishment. Also, apart from two national industrial actions-Nigeria Union of Petroleum and Natural Gas Workers (NUPENG) and Nigerian Union of Allied Health Professionals strikes-(affecting all states and regions of the federation), the rest occurred in the southern region of Nigeria as shown in Fig. 1.

\begin{tabular}{ll}
\hline 1- Obafemi Awolowo University & 9- Ebonyi State University \\
2- University of Lagos & 10- Ambrose Ali University \\
3- Ladoke Akintola University & 15- Imo State \\
4- Federal University of & $\begin{array}{l}\text { 16- Benue State University Teaching } \\
\text { Agriculture, Abeokuta }\end{array}$ \\
$\begin{array}{ll}\text { 5- Kogi State University } & \text { 17- National Orthopaedic Hospital, } \\
\text { Igbobi, Lagos }\end{array}$ \\
$\begin{array}{l}\text { 6- Adekunle Ajasin University, } \\
\text { Akungba-Akoko }\end{array}$ \\
7- University of Ibadan \\
8- Imo State University
\end{tabular}

In 2014, we reported on a cross-sectional study among healthcare workers in Nigeria. We studied a total of 150 healthcare workers, of which less than half (43.6\%) supported industrial action [1]. We reported that healthcare leadership and management were cited as the most common (92\%), as well as the most important (43.3\%), cause of healthcare worker industrial action in Nigeria [1]. Other cited causes were a demand for higher salaries and wages (82\%), infrastructural issues (63.3\%) and interpersonal issues (61.3\%). However, only $2.0 \%$ of respondents rated current healthcare management as excellent, while $24.0 \%$ rated it as very good.

Since the study involved different healthcare professionals, we decided to focus further investigation on physicians, who also were most implicated in the leadership challenge. Also, since the study concentrated on healthcare workers in Abuja, the Federal Capital Territory, we planned to involve all the regions of Nigeria in an expanded study. The aim of the study was to identify and document the frequency of physician-initiated strike actions in healthcare facilities and the views of physicians regarding these strike actions in terms of cause, effects and outcomes of the strikes.

\section{Methods}

We used a cross-sectional study design. Study populations were selected from physicians who attended the recently concluded West African College of Physicians (WACP)/Royal College of Physicians (RCP) Millennium Development Goal 6 Partnership for African Clinical Training (M-PACT) course, funded by the EcoBank Foundation in Nigeria. Such sampling ensured inclusion of participants from all the geopolitical regions of Nigeria. Participants were informed of the nature of the study and participation was by choice as non-participation was not associated with any negative consequences.

We used a self-administered, pre-tested for accuracy, analysability, acceptability and ambiguity, and properly tailored questionnaire. The pre-test was done among physicians who were not part of the selected study population, 


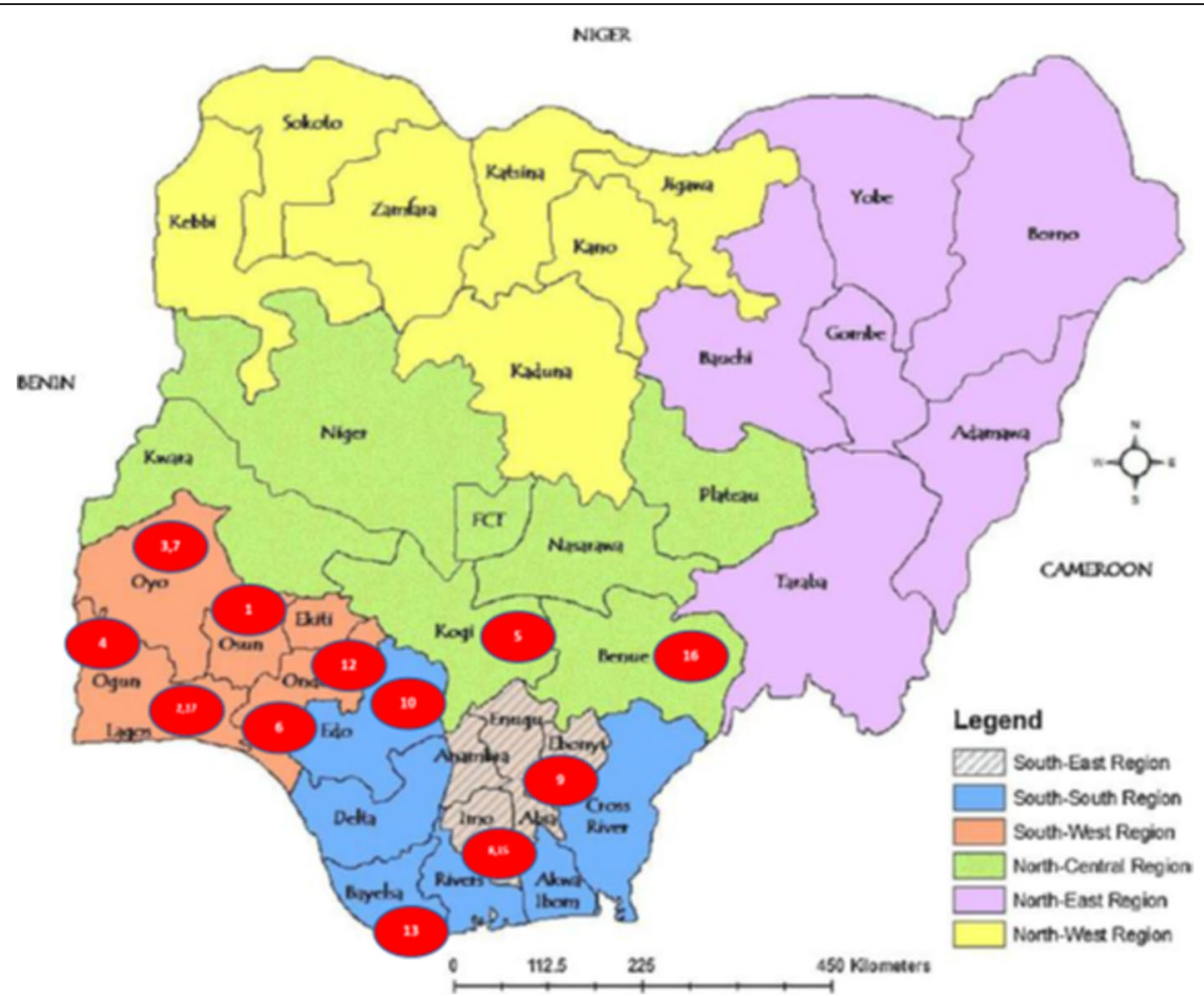

Fig. 1 Map showing locations of strike actions in Nigeria

and issues of ambiguity noticed in the questionnaire were corrected before the final study was carried out. The questionnaire had 23 different questions and the majority were open-ended to allow for proper participants' expressions of their views and to prevent biased responses from single option or closed questions. Approval for the study was obtained from the Board, Excellence and Friends Management Care Centre (EFMC) and respective partners in the United Kingdom (Royal College of Physicians of London).

Questionnaires were distributed through participants' emails, and each individual was given 14 days to respond to the questionnaires. No reminder email was sent, as this was also a test of participants' willingness to be part of a changed healthcare system.

Completed questionnaires were collected and retrieved online, screened for accuracy and completeness, and analysed using SPSS v 23 (SPSS Inc., Chicago, Illinois, USA). Simple frequencies were performed, and relevant tables/charts were developed. Sex, age, educational qualification, job status and the number of years in service were used in the analysis.

\section{Results}

A total of 58 physicians (out of 131 participants in the Nigerian courses, drawn from the first 2 years of the programme) responded to the study, giving a response rate of $44.3 \%$.

\section{Demographic characteristics of respondents}

Males constituted $62.1 \%$ of the respondents, and the majority were between 30 and 49 years of age (Table 1). Over $60 \%$ graduated before 2010, and of the 57 who responded to the question on their qualifications, $42.1 \%$ had additional qualifications and over $33.4 \%$ had a membership or fellowship qualifications of the West African College of Physicians. The majority of the participants were from the South South (14, 24.1\%) and South West (18. 31.0\%) geopolitical regions of Nigeria. The least represented region was the North East, where there has been an ongoing insurgency since 2010. Two non-Nigerians who attended the Nigerian courses also responded to the survey (Table 1).

Internal medicine $(12,27.3 \%)$ and community health $(16,29.1 \%)$ constituted the largest portion of the respondents.

\section{Frequency, nature and consequences of industrial action in healthcare establishments}

In 2016, there were between 0 and 6 different strike actions in each Nigerian healthcare institution with three strikes (3) as the most frequent number of industrial action taken (Fig. 2).

Over the past 3 years, participants reported that there has been between 1 and 15 different strike actions in the healthcare systems, with $88 \%$ claiming that there has been over six different strike actions and $16 \%$ over 11 
Table 1 Demographic characteristics of respondents

\begin{tabular}{|c|c|c|}
\hline & Frequency & Percent \\
\hline \multicolumn{3}{|l|}{ Age of respondents (years) } \\
\hline$<30$ & 6 & 10.7 \\
\hline $30-39$ & 38 & 67.9 \\
\hline $40-49$ & 11 & 19.6 \\
\hline $50-59$ & 1 & 1.8 \\
\hline Total & 56 & 100 \\
\hline Missing system & 2 & 3.4 \\
\hline \multicolumn{3}{|l|}{ Year of graduation of respondents } \\
\hline$<2000$ & 2 & 3.6 \\
\hline $2000-2004$ & 7 & 12.5 \\
\hline 2005-2009 & 35 & 62.5 \\
\hline 2010-2014 & 10 & 17.9 \\
\hline $2015+$ & 2 & 3.6 \\
\hline Total & 56 & 100 \\
\hline Missing system & 2 & 3.4 \\
\hline \multicolumn{3}{|l|}{ Academic qualification of respondents } \\
\hline MBBS/BDS & 57 & 100 \\
\hline $\mathrm{MPH}$ or MSC & 7 & 12.3 \\
\hline MWACP & 16 & 28.1 \\
\hline FWACP & 3 & 5.3 \\
\hline Total & 57 & 98.3 \\
\hline Missing system & 1 & 1.7 \\
\hline Total & 58 & 100 \\
\hline \multicolumn{3}{|l|}{ Geopolitical zones of participants } \\
\hline North Central & 8 & 14.3 \\
\hline North East & 1 & 1.8 \\
\hline North West & 4 & 7.1 \\
\hline South East & 9 & 16.1 \\
\hline South South & 14 & 25.0 \\
\hline South West & 18 & 32.1 \\
\hline Non-Nigerian & 2 & 3.6 \\
\hline Total & 56 & 100 \\
\hline Missing system & 2 & 3.4 \\
\hline \multicolumn{3}{|l|}{ Department/faculty of respondents } \\
\hline Internal Medicine & 15 & 27.3 \\
\hline Community Health & 16 & 29.1 \\
\hline Family Medicine & 7 & 12.7 \\
\hline General Practitioner & 12 & 21.8 \\
\hline Paediatrics & 3 & 5.5 \\
\hline Others & 2 & 3.6 \\
\hline Total & 55 & 100.0 \\
\hline Missing system & 3 & 5.2 \\
\hline \multicolumn{3}{|l|}{ Position/level in training } \\
\hline Medical Officer of Health/Registrar & 14 & 24.6 \\
\hline
\end{tabular}

Table 1 Demographic characteristics of respondents (Continued)

\begin{tabular}{lll}
\hline & Frequency & Percent \\
Age of respondents (years) & & \\
\hline Senior Registrar & 39 & 68.4 \\
Consultant/Fellow & 3 & 5.3 \\
Others & 1 & 1.7 \\
Total & 57 & 100 \\
Missing system & 1 & 24.6 \\
\hline
\end{tabular}

strike actions. Of these, $96.0 \%$ believed that at least one of the strikes was championed by doctors, with 19.2\% believing that physicians were responsible for three or more strike actions in the year (Table 2).

The commonest cause of strike in the healthcare care cited by $16.7 \%$ of the participants was staff welfare (Table 3). Compensation and salary issues, government, and leadership and management were cited by $13.9 \%$ as the next common cause of industrial action in healthcare in Nigeria. This was followed by poor infrastructure (11.1\%), poor guidelines and services (11.1\% each) and inter-professional disputes (5.6\%).

Healthcare worker strikes have various consequences. We classified these according to themes into seven main groups (Service Delivery impacts, Morbidity and Mortality impacts, Institutional impacts, Professional impacts; Healthcare outcomes impacts, Governmental impacts, and Training impacts) as shown in Table 4.

Although healthcare worker strikes have several negative consequences, they are also believed to be beneficial to a number of people including healthcare workers (21.8\%), private practitioners $(21.8 \%)$, union leaders $(5.5 \%)$ and sometimes the Government. However, the patients have suffered the most, according to $83.9 \%$ of the respondents (Table 5).

Proposed solutions to healthcare worker strikes in Nigeria On what could be done to stop or minimize the number of healthcare worker strikes in Nigeria in any given year, the respondents were of the view that the Government should respect agreements and implement the Nigerian National Health Act; hospital management and leaders should run an all-inclusive government with better communication strategies; healthcare workers should be actively involved and represented in decision making and management; salaries and wages should be improved and paid on time; and infrastructure and training systems should be improved upon. See Table 6 for sample unedited comments.

Also, $98.2 \%$ of the respondents were of the view that every physician should be trained in leadership skills. To achieve this, $87.3 \%$ were of the opinion that training in leadership should occur at both undergraduate and 


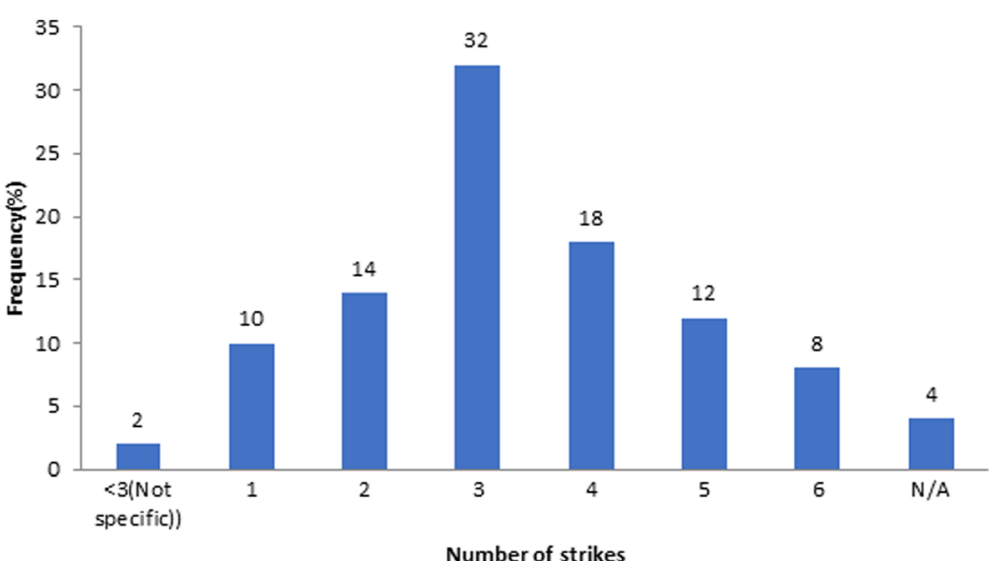

Fig. 2 Number of healthcare workers' strikes/industrial actions that took place in healthcare institution across Nigeria in 2016

graduate/fellowship levels. The rest $5.5 \%$ and $7.3 \%$ wanted the training at undergraduate and postgraduate levels, respectively. To achieve this, they identified major deficiencies in the current medical curriculum which they said was outdated, was too didactic and does not allow for lecturer-student relationship nor stimulate accountability in lectures, and has no training on leadership and entrepreneurship. Other obstacles identified in the current training system are documented in Table 7.

A respondent said, "Truly, medical training in Nigeria does not equip the doctor to lead beyond the clinical ward round sessions. The mentality of statutory leadership by doctors is currently being threatened because of

Table 2 Physician and other healthcare workers' mediated strike actions in Nigeria in 2016

\begin{tabular}{cccl}
\hline & Frequency & Percent & V. Percent \\
\hline Physicians mediated & healthcare worker strikes in Nigeria & \\
0 & 2 & 3.4 & 4.3 \\
1 & 14 & 24.1 & 29.8 \\
2 & 22 & 37.9 & 46.8 \\
3 & 5 & 8.6 & 10.6 \\
4 & 2 & 3.4 & 4.3 \\
5 & 2 & 3.4 & 4.3 \\
Total & 47 & 81 & 100 \\
Missing system & 11 & 19 & \\
Other healthcare workers mediated strike actions in 2016 & \\
0 & 2 & 4.45 & 4.45 \\
1 & 20 & 44.45 & 44.45 \\
2 & 17 & 37.8 & 37.8 \\
3 & 5 & 11.1 & 11.1 \\
4 & 1 & 2.2 & 2.2 \\
Total & 45 & 100 & 100 \\
Missing system & 13 & 22.4 & \\
\hline
\end{tabular}

the significant failure of the medical doctors who have and are still 'ruling' the sector. They have erroneously transferred the clinical model of patient care leadership to hospital management and the result is what we have today. Deliberate leadership and management training must be incorporated into the curriculum."

This was critical because for $60 \%$ of the respondents, the relationship between doctors and the employing institution was considered to be very bad (20\%) and bad (40\%), with only $12.7 \%$ saying it was good. No one said it was very good or excellent (Fig. 3).

\section{Discussion}

Although the response rate was poor, the findings of this study are very instructive. The study catalogues the thinking of medical doctors who have had the privilege to lead healthcare systems in Nigeria for a very long time, and who are still in leadership roles.

While over $82 \%$ of the respondents graduated from medical school on or before 2009, none had a definable leadership and management certificate/qualification. This is more informative as their subsequent comments showed that there had been little or no leadership and management education in their undergraduate and postgraduate training.

The very low response rate from North East of Nigeria could be a reflection of the ongoing insurgency in the area, which has caused many healthcare workers to flee the region, delaying patient access to quality healthcare as and when needed, and led to increased cost of healthcare, and morbidity and mortality in the area.

The higher rate of response from Medical Officers of Health/registrars and senior registrars in internal medicine and community health is probably a result of their higher representation in the WACP/RCP courses in Nigeria (from which the study participants were drawn), as they formed a major percentage of trained physicians 
Table 3 Common causes of healthcare worker strikes in Nigeria

\begin{tabular}{|c|c|c|c|}
\hline Description & Frequency & $\%$ & Type of comments made \\
\hline Government & 5 & 13.9 & $\begin{array}{l}\text { Failure of hospital management to uphold Federal Government (FG) agreements about salaries and allowances; } \\
\text { Breach of trust by the government and government insincerity; Unfulfilled agreements reached with the } \\
\text { Government on wages, training, equipping the hospital; Insincerity of FG and Chief Medical Directors (CMDs) } \\
\text { in keeping to agreements and manipulation of union heads by politicians; Change of Government }\end{array}$ \\
\hline Infrastructures & 4 & 11.1 & $\begin{array}{l}\text { Poor hospital utility facilities (No water in wards, Poor/No doctors' call room, etc.); Poor working environment; } \\
\text { Security of staff; and Poor infrastructure in the hospitals }\end{array}$ \\
\hline $\begin{array}{l}\text { Leadership and } \\
\text { management }\end{array}$ & 5 & 13.9 & $\begin{array}{l}\text { At the core of it is welfare issues like low staff motivation; Poor communication between hospital leadership/ } \\
\text { administration and healthcare workers; Hospital leadership quick to respond to circulars from the Federal } \\
\text { Ministry of Health (FMOH) that are anti-workers, but slow to respond to circulars that favour workers; Hospital } \\
\text { leadership disconnected from the true situation of things in the hospital and unmindful of the experiences } \\
\text { of patients; Leadership tussle }\end{array}$ \\
\hline Welfare & 6 & 16.7 & $\begin{array}{l}\text { For improvement in workers' welfare; Delayed promotion; Joint Health Sector Union's (JOHESU) demand to } \\
\text { be appointed consultants; Failure of the management to sponsor residents' exams and updates; Denial of } \\
\text { basic entitlement such as salary and training sponsorship }\end{array}$ \\
\hline $\begin{array}{l}\text { Compensation } \\
\text { and salary }\end{array}$ & 5 & 13.9 & $\begin{array}{l}\text { Poor workers' compensation; Inconsistent salaries; Delayed salary payment; Pay check is delayed and very } \\
\text { small to meet up with present day reality; Remuneration skipping/relativity }\end{array}$ \\
\hline $\begin{array}{l}\text { Inter-professional } \\
\text { disputes }\end{array}$ & 2 & 5.6 & Inter-professional disputes, unnecessary disharmony amongst healthcare workers \\
\hline $\begin{array}{l}\text { Poor guidelines } \\
\text { and services }\end{array}$ & 4 & 11.1 & $\begin{array}{l}\text { Poor guidelines for progression for different cadre of healthcare workers; Agitation for improved service delivery; } \\
\text { Upgrading the standard of health care delivery and assault on a health worker; Lack of residency training policy }\end{array}$ \\
\hline Others & 5 & 13.9 & $\begin{array}{l}\text { Lack of facilities, residency templates for residents; In solidarity with unjustly dismissed colleagues in order that } \\
\text { they be reinstated; For regularization of entry and other grade levels; Greed; Protest against sack of residents } \\
\text { who have overstayed }\end{array}$ \\
\hline
\end{tabular}

over the period of study. The views captured in this study may also reflect their understanding of the system and their level of training. For future studies, it would be instructive to study more senior doctors including consultants and fellows to compare their views with those of the junior officers highlighted in this study.

This study shows that healthcare workers' strikes were common across the nation-but majority occurred in the southern regions. There were no public healthcare workers in the country who had not embarked on one or more episodes of industrial action during the period under review with its attendant consequences. This, we believe, is both disruptive and detrimental to the healthcare system in Nigeria. Furthermore, the majority of the strike actions were initiated by physicians, who also lead the healthcare facilities, thus, undermining indirectly, what they are mandated to lead and maintain.

Table 4 Common consequences of healthcare worker strikes in Nigeria

\begin{tabular}{ll}
\hline Description & Comments on strike consequences \\
\hline Service delivery impacts & $\begin{array}{l}\text { Skeletal services; Patients are unable to access healthcare services; Poor patient care; Patients suffer as patients that } \\
\text { need attention are denied specialist attention; Beneficial departmental activities are stalled/cancelled; Disruption in } \\
\text { service rendition }\end{array}$ \\
Morbidity and mortality & $\begin{array}{l}\text { Loss of lives; Increased morbidity and its complications, increase in maternal and child mortality, overall mortality and } \\
\text { morbidity: Patients who cannot afford private facility bills may end up dying }\end{array}$ \\
Inpacts & $\begin{array}{l}\text { Reduced revenue generation by the hospitals; Loss of confidence in the system; Industrial actions weaken the health } \\
\text { system and constantly dragging the system backwards; negatively affects the productivity of a particular institution; } \\
\text { Increased distrust of the public health system by the general public, dissatisfaction of clients/patients; Conflicts between } \\
\text { employees and management: Reduced internally generated revenues; Disruption in key health services including } \\
\text { immunization and Prevention of Mother-to-child Transmission of HIV (PMTCT) services; Low productivity }\end{array}$
\end{tabular}

Professional impacts L Loss of dignity and respect for the profession; Poor public perception of medical personnel; Unhappy doctor; Reduced efficiency of human and material resources; Unhealthy inter- and intra-health workers relationships

Healthcare outcomes Distortions of patient care outcome parameters (both clinical and patient satisfaction)

impacts

Government agencies responsible for reason for strike actions suddenly wake up to respond to the agitated needs; Medical tourism and capital flight

Training impacts 
Table 5 Groups and individuals that benefit from or are impacted by healthcare worker strikes

\begin{tabular}{lll}
\hline Description & Frequency & Percent \\
\hline Groups and individuals that benefits & from healthcare & worker strikes \\
No one & 26 & 47.3 \\
Healthcare workers & 12 & 21.8 \\
Private hospitals/practitioners & 12 & 21.8 \\
Union leaders & 3 & 5.5 \\
Not sure & 2 & 3.6 \\
Government & 3 & 5.5 \\
Patient & 1 & 1.8 \\
Consultants & 1 & 1.8 \\
Groups and individuals negatively impacted by healthcare worker strikes \\
Patients & 47 & 83.9 \\
Patients and their relatives & 3 & 5.4 \\
General public & 6 & 10.9 \\
Residents doctors & 6 & 10.9 \\
Poor socio-economic class & 3 & 5.4 \\
Government & 2 & 3.6 \\
\hline
\end{tabular}

The key causes of healthcare workers' industrial actions mentioned by the respondents included Government's inability to implement agreements, infrastructural challenges, poor leadership and management with inadequate communication strategies, poor staff welfare, inadequate and delayed salaries, inter-professional disputes and poor adherence to practice guidelines and policies. These are similar to findings from our earlier study [1]. Although there was not a marked difference in the number of respondents who cited leadership and management from the rest, if staff welfare challenges such as delayed promotion, failure of the management to sponsor residents' exams and updates, denial of basic entitlement such as salary, and training sponsorship were classified as leadership and management problems, leadership and management can be seen to be the most common cause of healthcare workers' industrial action as documented before [1].

Healthcare workers' strikes have several devastating consequences on the healthcare system including disruption in service delivery, increased morbidity and mortality of patients, reduced revenue generation for hospitals, loss of confidence in hospitals and the healthcare profession, poor patient care outcome parameters, and disruption of training programmes with longer stay of residences within the healthcare system. Apart from a possible improvement in governmental engagement and conversation with healthcare workers, all outcomes of strikes are seen to be negative and highly disruptive to the healthcare system. Other respondents' documented benefits to healthcare workers, private practitioners and government may be seen to be detriment of the patient who suffers most from all strike actions, as noted by $83.9 \%$ of the respondents.

A study was carried out during a 20-day strike in a hospital in South Africa, and it provided evidence of significantly lowered quality of service delivery with an overall reduction in the number of admissions and surgeries performed in the hospital when compared to a non-striking situation as hospital mortality, when correlated with number of hospital admissions, increased threefold for the hospital as a whole while mortality doubled in the surgical department during strike actions [7]. However, a review of the impact of healthcare strikes in other

Table 6 Suggested solutions to national healthcare worker strikes in Nigeria

\begin{tabular}{ll}
\hline Theme & Samples of comments on solutions to healthcare worker strikes \\
\hline $\begin{array}{l}\text { Government respect for agreements } \\
\text { and health acts }\end{array}$ & $\begin{array}{l}\text { Government should implement the signed agreements, not just put them to paper; Fulfilment of agreement } \\
\text { by Government to all health workers; Improvement in health service delivery including implementation of } \\
2014 \text { National Health Act. More sincerity on the part of Government }\end{array}$ \\
$\begin{array}{l}\text { Better leadership and management } \\
\text { systems }\end{array}$ & $\begin{array}{l}\text { Hospital management should communicate better with residents (not by issuing threats); The hospitals } \\
\text { should operate at an internationally acceptable standard for the kind/level of facility it is; The hospital } \\
\text { administration/leadership should involve the healthcare workers in decision making, leadership should be } \\
\text { inclusive; To work on the leadership and administration of the health system; Sincerity on the part of hospital } \\
\text { management }\end{array}$
\end{tabular}

Improved inter-professional relationships

Timely and better salaries and compensations

Infrastructural upgrade

Improve staff welfare

Better training management systems
Mutual respect among all healthcare cadres

Consistent and regular payment of salaries; Regularization of salaries to remove inconsistency; The remuneration of the health worker should be given topmost priority by the government and if they are unwilling, they can privatize hospitals for better management

Improved infrastructure in hospitals; Improved working conditions-renovations of the call rooms, Make working environment conducive

Increase welfare of health workers

There should be a clear template for the residency training programme which is universally applicable in all facilities in the country, and this should be followed strictly, including staff strength, work duration(s), remunerations, and taxation 
Table 7 Major deficiencies in the current curriculum for medical students

\begin{tabular}{|c|c|}
\hline Theme & Comments on training deficiencies \\
\hline $\begin{array}{l}\text { Faculty and } \\
\text { lecturers }\end{array}$ & $\begin{array}{l}\text { Poor quality and mindset of the teachers (a lot of the teachers were seen as being not ethical in their leadership conduct and } \\
\text { this has had a negative effect on the students, i.e. bullying behaviour during teaching sessions from consultants and registrars.); } \\
\text { Lack of/Poor mentorship; Negligence of meritocracy; Poor staffing; Lack of commitment of consultants to residency training; } \\
\text { Consultants were seen as being too busy to impact sound training for residents; Poor mentorship and commitment to residency } \\
\text { training; Poor supervision by the trainers }\end{array}$ \\
\hline Funding & $\begin{array}{l}\text { There is also the challenge of poor funding, obsolete teaching methods and facilities; Inadequate funding; Poor health system } \\
\text { funding. }\end{array}$ \\
\hline Infrastructure & $\begin{array}{l}\text { Overcrowded classrooms, poor amenities, too many distractions for medical students; Lack of essential equipment for skill } \\
\text { acquisition; Lack of/Poor medical infrastructure; Lack of adequate facilities even in accredited institutions; Lack of equipment }\end{array}$ \\
\hline $\begin{array}{l}\text { Research and } \\
\text { development }\end{array}$ & Lack of sponsorship for research in tertiary institutions; The major deficiencies are lack of investigative materials. \\
\hline Curriculum & $\begin{array}{l}\text { Lack of leadership and administrative training in the medical training; Deficiencies in curriculum, deficiencies in training } \\
\text { guidelines, deficiencies in training institutions, on-appraisal of what is existing already and creating a benchmark for operation; } \\
\text { Lack of harmonization of training curriculum; Non-inclusion of leadership/management training, policy-making and research } \\
\text { with hands-on experience even at the postgraduate level especially as doctors are expected to lead the health team }\end{array}$ \\
\hline Career path & $\begin{array}{l}\text { Lack of job security during and after the programme; Spaces for new fellows seem to be shrinking; The exams were considered } \\
\text { to be biased; More emphasis on passing exams than on skill acquisition }\end{array}$ \\
\hline Strikes & $\begin{array}{l}\text { Frequency of strikes; Incessant interruptions during the period of residency training; Interruption/ prolongation of residency } \\
\text { training programme }\end{array}$ \\
\hline
\end{tabular}

parts of the world, especially in developed countries, has shown that healthcare workers' strikes may not significantly affect the health of patients, especially if there is the availability of emergency services or affordable private fee-for-service care [8]. By contrast, this is not the case in Nigeria as there have never been contingency plans for the welfare of the patients before and during these strikes.

Studies conducted in hospitals in Sweden, Israel and the United States of America during periods of strike action showed an increase in patient volume at emergency units for emergency care, diagnosis and treatment [810]. Mortality rates either remained constant or decreased, due to a reduction in the number of elective surgeries performed [8, 11]. Although there were no deaths from elective surgeries because they were cancelled, it was observed that there was an increased number of deaths, which occurred during transfers between emergency rooms [11]. Studies have also shown that patients from lower socio-economic strata of the society are less able to cope with healthcare workers' strikes probably because they are unable to afford alternative or private healthcare services $[8,11]$. These underline the need to eliminate healthcare worker strikes as they result in avoidable deaths and morbidities.

In this study, several mitigating steps were suggested and these include that the Government (at all levels) should respect agreements and implement the Nigerian National Health Act, as also recommended in a case study by Adeloye et al. [12]. The National Health Act intends to positively impact universal health coverage, access to and cost of healthcare, funding and insurance

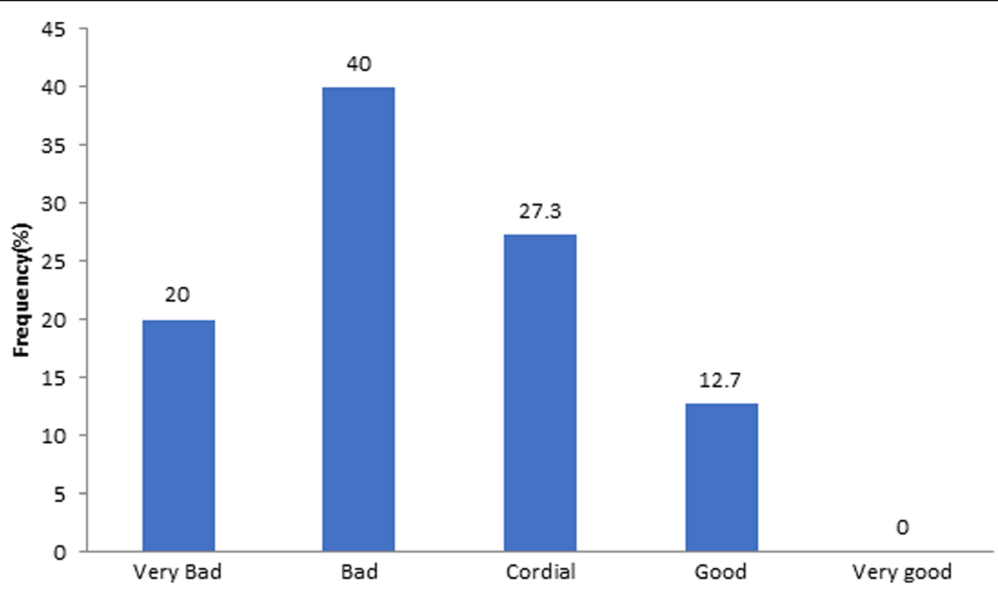

Fig. 3 Current relationship between doctors and hospital management 
facilities, practice by healthcare providers, quality and standards, patient care and health outcomes [12]. Respondents in our study also believe that there should be provision of better leadership and management systems for the healthcare industry; workers and Government should partner to improve inter-professional relationships, while salaries and financial remuneration should be timely and appropriate. Other welfare matters should be investigated in a timely fashion and improved upon, workplaces should be made more appropriate with infrastructural upgrade and provision of relevant equipment, and training programmes should be standardized with appropriate clinical and practice guidelines, policies and standards of practice developed.

To minimize strikes, the respondents suggested that hospital management should communicate better with residents and that hospitals should operate at an internationally accepted standard for the kind/level of facility it is. This includes involving healthcare workers in decision making; leadership should be inclusive; mutual respect among all healthcare cadres; consistent and regular payment of salaries and regularization of salaries to remove inconsistency; improved infrastructure in hospitals with better working conditions; and establishment of a clear template for the residency training programme which is universally applicable in all facilities in the country.

The Joint Learning Initiative on Human Resources for Health and Development, Report, in response to the demotivation of healthcare workers which moves them to strike action, states that "a key action is a significant upward revision of the total compensation package to a level that reflects the value placed on the work they do, is likely to discourage staff from wanting to leave public sector services" [13]. Moreover, to improve the leadership and management standards of the industry which will drastically reduce the number of healthcare workers who strike, over $98 \%$ of the respondents were of the view that every physician should be trained in leadership skills at both undergraduate and graduate/fellowship levels. This will require modification of the current medical curriculum, improvement in lecturer-student relationships and improvement in the level of accountability of lecturers. Also, as managers of finances and materials resources, physicians should be trained in financial management and entrepreneurship.

We agree with Adeloye et al. that the Nigerian health system requires a solid administrative policy foundation that will allow for alignment and coordination of partnerships among various stakeholders in the health workforce [12]. We believe that to develop competency in public health leadership, public health leaders require competency-based instruction to increase their ability to address complex and changing demands for critical services [14]. With a spirit of cooperation, it should be possible to minimize or completely eliminate healthcare workers' strikes in Nigeria.

\section{Limitations}

Online distribution of questionnaire for a study has its various limitations which include poor response rates. Although this was noticed in this study, a response rate above $40 \%$ is significant and deductions made are statistically viable. We could not study the characteristics of the non-responders to determine if they were different from the responders. Also, we focused on physicians who just attended a course. This may have influenced their views and understanding of physician leadership roles.

Convenience sample was used for this study. In addition, the study population is limited to only physicians who attended the course. Therefore, the results of this study may not be generalized to all doctors in Nigeria because surgeons and other specialist were not included in the study.

As the study was small and limited in nature, it was supposed to be approved by the Board of Excellence and Friends Management Care Centre (EFMC), but as two of the authors are also Board members, this may create "a potential conflict of interest". So, to avoid this, the EFMC Board members were not part of those that approved the work. The national ethical committee will approve subsequent works in this area.

\section{Conclusions}

This cross-sectional study has again highlighted the common causes and consequences of healthcare worker strike actions in Nigeria. To minimize these, the Federal Government must respect all agreements made with the management of healthcare institutions, implement the National Health Act, ensure that only appropriately trained leaders and managers are given the responsibility of managing the hospitals in the country, work to ensure that salaries and financial remuneration are fair and paid on time, improve the work environment by providing necessary work tools and equipment and improve the welfare of staff, especially those working in difficult environments. The Government should also standardize training programmes in all institutions.

Although the Government has a significant role to play, physicians who lead must lead well, ensuring that they acquire the right set of skills and competencies in leadership through formal and tailored health policy, leadership and management training, and manage the healthcare system dispassionately with fairness. Nigerian medical professionals must all work together to minimize the disruption to healthcare service delivery, with the attendant morbidity and mortality. Improvement of institutional, professional and healthcare outcomes can only be brought about in a spirit of collaboration. This will help rebuild the lost confidence of the people in the healthcare system and improve community health. 
Future studies should also investigate other ethical aspects of the practice of medicine in this environment and how the impact of training in medical ethics or ethics of the healthcare professions in the current medical curricula in Nigeria, or lack thereof, might influence the frequent incidence strikes in Nigeria.

\section{Abbreviations}

FG: Federal Government; JOHESU: The Joint Health Sector Union; MPACT: Millennium Development Goal 6 Partnership for Clinical Training: RCP: Royal College of Physicians; WACP: West African College of Physicians

\section{Acknowledgements}

SDT-R is grateful to the NIHR Biomedical Facility at Imperial College London for infrastructure support. Other authors are grateful to the Institute of Human Virology Nigeria (IHVN) and Excellence \& Friends Management Care Centre (EFMC) for institutional support.

\section{Funding}

We acknowledge the Wellcome Trust for their support.

\section{Availability of data and materials}

Data is available for further review on request.

\section{Authors' contributions}

O०O developed the concept, coordinated the research and wrote and approved the final draft of the article. He also serves as the corresponding author. DU collated and analysed the data with support from 000.00 edited the work, completed the discussion and developed the abstracts. SDT-R made inputs to all sections of the manuscript and is the guarantor of the article. TAl supported the development, distribution and collation of questionnaires. She also worked with DU in cleaning of data and data analysis. All authors read and approved the final manuscript.

\section{Ethics approval and consent to participate}

Ethical approval was obtained from the EFMC Board, and consent was obtained from all participants before their participation in the study.

\section{Consent for publication}

Not applicable.

\section{Competing interests}

The authors declare that they have no competing interests.

\section{Publisher's Note}

Springer Nature remains neutral with regard to jurisdictional claims in published maps and institutional affiliations.

\section{Author details}

${ }^{1}$ Excellence \& Friends Management Care Centre (EFMC), P. O. Box 200, PSIN Dutse, Abuja, Nigeria. ${ }^{2}$ APIN Public Health Initiatives, Ltd., Abuja, Nigeria. ${ }^{3}$ Hepatology Unit, Imperial College London St Mary's Hospital Campus, 10th Floor, QEQM Building, South Wharf Road, London W2 1NY, United Kingdom.

Received: 16 August 2017 Accepted: 8 October 2018

Published online: 17 October 2018

\section{References}

1. Oleribe $\mathrm{OO}$, Ezieme IP, Oladipo O, Akinola EP, Udofia D, Taylor-Robinson SD. Industrial action by healthcare workers in Nigeria in 2013-2015: an inquiry into causes, consequences and control-a cross-sectional descriptive study. Hum Resour Health. 2016;14(1):46.

2. BREAKING: NUPENG Calls Off Tanker Drivers' Strike. Posted by Deolu on Apri 3, 2017. Retrieved on 12.07.2017 from https://www.informationng.com/ 2017/04/breaking-nupeng-calls-off-tanker-drivers-strike.html.

3. Toromade S. 10 universities that went on strike this year: Published: 14.12 2016. Refreshed: 15.12.2016. Retrieved on 12.07.2017 from http://www.pulse. ng/student/pulse-list-2016-10-universities-that-went-on-strike-this-yearid5893677.html.
4. Ahiuma-Young V, Agbakwuru J. NUPENG begins 3-day strike today, as FG moves to stop action. Published on January 11, 2017. Retrieved on 12.07. 2017 from http://www.vanguardngr.com/2017/01/nupeng-begins-3-daystrike-today-fg-moves-stop-action/.

5. Kershio T, Nathaniel A. BSUTH JOHESU Congress resolutions that led to strike action suspension. Posted on 15/Jun/2017. Retrieved on 12.07.2017 from http://www.nursingworldnigeria.com/2017/06/bsuth-johesu-congressresolutions-that-led-to-strike-action-suspension.

6. Obinna C. Igbobi Hospital workers call off warning strike. Posted on March, 14, 2017. Retrieved on 12.07.2017 from http://www.vanguardngr.com/2017/ 03/igbobi-hospital-workers-call-off-warning-strike/.

7. Bhuiyan M, Machowski A. Impact of 20-day strike in Polokwane Hospital (18 August - 6 September 2010). S Afr Med J. 2012;102:9 Cape Town Sep. Retrieved on 18.07.2017 from https://www.ncbi.nlm.nih.gov/pubmed/ 22958699.

8. Chima SC. Global medicine: is it ethical or morally justifiable for doctors and other healthcare workers to go on strike? BMC Medical Ethics. 2013; 14(Suppl 1):S5. Retrieved on 18.07.2017 from https://bmcmedethics. biomedcentral.com/articles/10.1186/1472-6939-14-S1-S5.

9. Slater PE, Ever-Hadani P, Adler Y, Ellencweig AY. Emergency department utilization during a doctors' strike. Am J Emerg Med. 1984;2(6):486-90.

10. Grosskopf I, Buckman G, Garty M. Ethical dilemmas of the doctors strike in Israel. J Med Ethics. 1985;11:70-1. https://doi.org/10.1136/jme.11.2.70. Retrieved on 18.07.2017 from http://jme.bmj.com/content/medethics/11/2/70.full.pdf.

11. Stovall JG, Hobart M, Geller JL. The impact of an employees' strike on a community mental health center. Psychiatr Serv. 2004;55:188-91. https://doi. org/10.1176/appi.ps.55.2.188. Retrieved on 18.07.2017 from http://ps. psychiatryonline.org/doi/full/10.1176/appi.ps.55.2.188.

12. Adeloye $D$, et al. Health workforce and governance: the crisis in Nigeria. Hum Resour Health. 2017;15:32. https://doi.org/10.1186/s12960-017-0205-4. Retrieved on 18.07.2017 from https://www.researchgate.net/publication/ 316911242_Health_workforce_and_governance_The_crisis_in_Nigeria.

13. The JLI Africa Working Group: a report of the Africa Working Group of the Joint Learning Initiative on Human Resources for Health and Development, September 2006. The health workforce in Africa challenges and prospects 2013. http://www.who.int/entity/hrh/documents/HRH_Africa_JLlreport.pdf

14. Wright $\mathrm{K}$, Rowitz $\mathrm{L}$, Merkle A, et al. Competency development in public health leadership. Am J Public Health. 2000;90(8):1202-7. Retrieved on 18.07 2017 from https://www.ncbi.nlm.nih.gov/pmc/articles/PMC1446322/pdf/ 10936996.pdf

\section{Ready to submit your research? Choose BMC and benefit from:}

- fast, convenient online submission

- thorough peer review by experienced researchers in your field

- rapid publication on acceptance

- support for research data, including large and complex data types

- gold Open Access which fosters wider collaboration and increased citations

- maximum visibility for your research: over $100 \mathrm{M}$ website views per year

At $\mathrm{BMC}$, research is always in progress.

Learn more biomedcentral.com/submissions 